\title{
Update on Glucocorticoid Induced Osteoporosis
}

\author{
Soo-Kyung Cho, Yoon-Kyoung Sung \\ Department of Rheumatology, Hanyang University Hospital for Rheumatic Diseases, Seoul, Korea
}

Glucocorticoids are used to treat many autoimmune and inflammatory diseases. However, an adverse systemic effect is a deleterious effect on bone, which may lead to glucocorticoid-induced osteoporosis, characterized by a rapid and transient increase in bone resorption and fracture risk, which may increase rapidly within 3 months of commencing oral glucocorticoids. Therefore, early risk assessment and intervention are crucial for preventing fractures in patients receiving glucocorticoids. Recent practice guidelines recommend an assessment for fracture risk in patients beginning or receiving glucocorticoids for more than 3 months, and they have suggested fracture risk assessment tool values for identifying patients who need preventive treatment. Bisphosphonates are currently the recommended first-line therapy for the prevention and treatment of glucocorticoid-induced osteoporosis. These have been shown to increase the bone mineral density in the spine and hip and to decrease the incidence of vertebral fractures. Recently, a more potent antiresorptive agent, denosumab, has been shown to increase the bone density in patients receiving glucocorticoids. Teriparatide has been shown to have a preventive effect on vertebral fractures, but not on nonvertebral fractures. In this article we aimed to provide an update on glucocorticoid-induced osteoporosis by focusing on the assessment of its risk and treatment options.

Keywords: Glucocorticoids; Osteoporosis; Therapeutics

\section{INTRODUCTION}

Glucocorticoids (GCs) are potent anti-inflammatory drugs first introduced in the 1950s to treat rheumatoid arthritis (RA) [1]. Since then, the efficacy of GCs in a number of autoimmune and inflammatory disorders has been proven [2]. Several studies from the United States and European countries have estimated the prevalence of GC use to range from $0.7 \%$ to $17.1 \%$ [3-7], and the prescription rate of long-term oral GC has increased by $34 \%$ over the past 20 years [4]. In Korea, a recent study demonstrated that the prevalence of chronic oral GC use for $\geq 30$ days increased from $0.16 \%$ in 2002 to $0.54 \%$ in 2015 [8].

GCs have been reported to result in decreased bone density and increased fracture risk. Approximately $12 \%$ of patients on

Received: 4 March 2021, Revised: 17 April 2021, Accepted: 19 April 2021

Corresponding author: Yoon-Kyoung Sung

Department of Rheumatology, Hanyang University Hospital for Rheumatic

Diseases, 222-1 Wangsimni-ro, Seongdong-gu, Seoul 04763, Korea

Tel: +82-2-2290-9207, Fax: +82-2-2298-8231, E-mail: sungyk@hanyang.ac.kr chronic GC treatment are diagnosed with symptomatic fractures [9], and $27 \%$ to $51 \%$ have radiographic evidence of vertebral fractures [10]. Furthermore, there are multiple risk factors for osteoporosis other than inflammation, including old age, female sex, menopause, and decreased physical activity in patients with inflammatory diseases such as RA [11]. Glucocorticoid-induced osteoporosis (GIOP) is characterized by a rapid and transient increase in bone resorption, accompanied by a long-lasting inhibition of bone formation and osteocyte activity [12]. Consequently, fracture risk increases rapidly within the first 3 months of GC treatment, regardless of decreasing bone mineral density (BMD) $[13,14]$. Therefore, early intervention for GIOP is critical to prevent fractures. Nevertheless, many patients receiving GC are not evaluated for their skeletal health [15] and are treat-

\section{Copyright $\odot 2021$ Korean Endocrine Society}

This is an Open Access article distributed under the terms of the Creative Commons Attribution Non-Commercial License (https://creativecommons.org/ licenses/by-nc/4.0/) which permits unrestricted non-commercial use, distribution, and reproduction in any medium, provided the original work is properly cited. 
ed inadequately [16]; therefore, awareness of GIOP needs to be emphasized.

In this review article, we intend to provide an update of GIOP, focusing on the assessment of its risk and treatment options. Although the endogenous form of GIOP should also be managed [17], we focused on exogenous GIOP in this article.

\section{PATHOPHYSIOLOGY}

The direct effects of GCs on bone have been characterized by two distinct phases [18]. First, osteoclastogenesis during GC treatment increases, which leads to bone resorption mediated by an upregulation of receptor activator of nuclear factor kappa-B ligand (RANKL) and macrophage colony-stimulating factor with decreasing osteoprotegerin [19,20]. A negative uncoupling between bone formation and bone resorption is believed to be crucial for early and rapid bone loss [21]. The next phase is mediated by a reduction in circulating osteoblasts. GCs upregulate the expression of peroxisome proliferator-activated receptorgamma (PPAR- $\gamma$ ), which subsequently increases the differentiation of precursor cells towards adipocytes rather than osteoblasts, thus reducing osteoblast differentiation and formation [22]. Osteoblastogenesis mediated by the Wnt/ $\beta$-catenin signaling pathway is also inhibited by GCs. GCs inhibit Wnt binding by increasing the expression of Dickkopfl, which leads to a decrease in osteoblastogenesis [23-25].

\section{EPIDEMIOLOGY}

GIOP is the most frequent cause of secondary osteoporosis worldwide [12]. Many epidemiological studies have demonstrated that increased fracture risk is associated with the dose and duration of GC treatment [13,26,27]. Low (2.5 to $7.5 \mathrm{mg}$ ) doses of prednisone-equivalents per day can be associated with fracture, especially in vertebral fractures (1.7- to 2.5-fold increase) $[13,27]$. The risk of this increases rapidly within 3 to 6 months of commencement of GC treatment and is greater in patients exposed to higher doses continuously for a longer period [28,29].

\section{TREATMENT THRESHOLD IN PATIENTS ON GCs}

Various guidelines for the management of GIOP have been developed and updated by several academic societies (Table 1) [30-42]. The Korean GIOP guideline was recently developed by adapting established guidelines from other countries [30]. However, the intervention thresholds differ between guidelines. A recent report evaluated and compared the treatment threshold in patients with GC because it is important to set appropriate thresholds to prevent fractures in GIOP [43].

Most guidelines recommend an assessment of fracture risk in patients beginning or receiving GC treatment for more than 3 months. Although most guidelines that were published before 2012 propose BMD assessment as a single tool for estimating the fracture risk, more recent criteria for identifying patients for preventive treatment have suggested country-specific fracture risk assessment tool (FRAX) values. Some guidelines use both tools to put steps in the assessment; the National Osteoporosis Guideline Group (NOGG) provides an algorithm to perform BMD when an individual is at intermediate risk, as calculated by the FRAX [31], and the Spanish Society of Rheumatology (SER) suggests that BMD is required if the 10-year probability of major osteoporotic fracture using FRAX is greater than 5\% [32]. The guidelines from the American College of Rheumatology (ACR) [33] and the Korean Society for Bone and Mineral Research (KSBMR)/the Korean College of Rheumatology (KCR) [30] separately present recommendations for younger patients. They suggested that BMD should be assessed in adults under 40 years of age at a high fracture risk.

Guidelines for GIOP published before 2012 use only a single criterion for the treatment threshold, while recently published guidelines present several criteria for defining thresholds. A dose greater than 5 or $7.5 \mathrm{mg}$ of prednisone equivalents per day with a 3-month minimum duration was proposed as a threshold for preventive treatment in most guidelines [31,34-41]. Additionally, according to some guidelines, GC users with prior fragility fractures or elderly patients are eligible for the initiation of anti-osteoporosis treatment, regardless of the presence of other risk factors.

A T-score of -2.5 in BMD is usually applied according to the guidelines for postmenopausal osteoporosis treatment; however, some guidelines suggest less stringent T-score values $(\leq-1.5)$. However, there is no established T-score threshold for boneprotective therapy in patients on GCs.

For FRAX, the intervention thresholds are divided into agedependent thresholds and fixed thresholds, according to the guidelines. The International Osteoporosis Foundation and the European Calcified Tissue Society, the Bone Section of the French Society for Rheumatology (SFR)/Osteoporosis Research and Information Group (GRIO), and NOGG guidelines recommend treatment for postmenopausal women and men over 50 


\begin{tabular}{|c|c|c|c|}
\hline Guideline & Initial fracture risk assessment & Intervention thresholds & Subject \\
\hline SER (2019) [32] & $\begin{array}{l}\text { FRAX } \\
\text { BMD (if FRAX 10-year risk of } \\
\text { major osteoporotic } \\
\text { fracture } \geq 5 \% \text { ) }\end{array}$ & $\begin{array}{l}\text { Postmenopausal women and men aged } \geq 50 \text { years with } \mathrm{GC} \geq 5 \mathrm{mg} / \text { day } \\
\text { BMD T-score } \leq-1.5 \mathrm{OR} \\
\text { FRAX } 10 \text {-year risk of hip fracture } \geq 3 \% \text { OR } \\
\text { FRAX } 10 \text {-year risk of major osteoporotic fracture } \geq 10 \% \text { without BMD } \\
\text { OR } \\
\text { FRAX 10-year risk of major osteoporotic fracture } \geq 7.5 \% \text { with BMD } \\
\text { Premenopausal women and men aged }<50 \text { years with GC } \geq 7.5 \mathrm{mg} / \text { day } \\
\text { BMD Z-score } \leq-3\end{array}$ & $\begin{array}{l}\text { All adults } \\
\text { Prior fragility } \\
\text { fracture OR } \\
\text { Initial GC } \\
\quad \geq 30 \mathrm{mg} / \text { day }\end{array}$ \\
\hline \multirow[t]{2}{*}{$\begin{array}{l}\mathrm{KSBMR} / \mathrm{KCR}(2018) \\
{[30]}\end{array}$} & $\begin{array}{l}\text { Adults aged } \geq 40 \text { years } \\
\text { FRAX (GC-adjusted) } \\
\text { BMD (within } 6 \text { months of GC } \\
\text { initiation) }\end{array}$ & $\begin{array}{l}\text { Adults aged } \geq 40 \text { years } \\
\text { BMD T-score } \leq-2.5 \text { (postmenopausal women and men aged } \geq 50 \text { years) } \\
\text { OR } \\
\text { FRAX } 10 \text {-year risk of major osteoporotic fracture } \geq 10 \% \text { OR } \\
\text { FRAX } 10 \text {-year risk of hip fracture }>1 \%\end{array}$ & $\begin{array}{l}\text { All adults } \\
\text { Prior fragility } \\
\text { fracture OR } \\
\text { Very high dose } \mathrm{GCs}^{\mathrm{c}} \\
\quad \text { (age } \geq 30 \text { years) }\end{array}$ \\
\hline & $\begin{array}{l}\text { Adults aged }<40 \text { years } \\
\text { BMD at high risk (within } \\
6 \text { months of GC initiation) }\end{array}$ & $\begin{array}{l}\text { Adults aged }<40 \text { years with } \mathrm{GC} \geq 7.5 \mathrm{mg} / \text { day } \\
\text { BMD Z-score }<-3 \mathrm{OR} \geq 10 \% / \text { year loss of BMD }\end{array}$ & \\
\hline \multirow[t]{2}{*}{ ACR (2017) [33] } & $\begin{array}{l}\text { Adults aged } \geq 40 \text { years } \\
\text { FRAX (GC-adjusted) } \\
\text { BMD (if available) (within } \\
6 \text { months of GC initiation) }\end{array}$ & $\begin{array}{l}\text { Adults aged } \geq 40 \text { years } \\
\text { BMD T-score } \leq-2.5 \text { (postmenopausal women and men aged } \geq 50 \text { years) } \\
\text { OR } \\
\text { FRAX 10-year risk of major osteoporotic fracture } \geq 10 \% \text { OR } \\
\text { FRAX } 10 \text {-year risk of hip fracture }>1 \%\end{array}$ & $\begin{array}{l}\text { All adults } \\
\text { Prior fragility } \\
\text { fracture OR } \\
\text { Very high dose } \mathrm{GCs}^{\mathrm{c}} \\
\quad \text { (age } \geq 30 \text { years) }\end{array}$ \\
\hline & $\begin{array}{l}\text { Adults aged }<40 \text { years } \\
\text { BMD at high risk (within } \\
6 \text { months of GC initiation) }\end{array}$ & $\begin{array}{l}\text { Adults aged }<40 \text { years with } \mathrm{GC} \geq 7.5 \mathrm{mg} / \text { day } \\
\text { BMD Z-score }<-3 \mathrm{OR} \geq 10 \% / \text { year loss of BMD }\end{array}$ & \\
\hline NOGG (2017) [31] & $\begin{array}{l}\text { FRAX }(\mathrm{GC} \text {-adjusted })^{\mathrm{b}} \\
\text { BMD at intermediate risk }\end{array}$ & $\begin{array}{l}\text { Postmenopausal women and men aged } \geq 50 \text { years } \\
\text { Age } \geq 70 \text { years OR GC } \geq 7.5 \mathrm{mg} / \text { day OR FRAX above intervention } \\
\text { threshold } \\
\text { Premenopausal women and men aged }<50 \text { years } \\
\text { High dose GCs }\end{array}$ & $\begin{array}{l}\text { All adults } \\
\text { Prior fragility } \\
\text { fracture }\end{array}$ \\
\hline SIOMMMS (2016) [41] & DeFRA(GC-adjusted) & $\begin{array}{l}\text { Postmenopausal women and men aged } \geq 50 \text { years } \\
\text { GC } \geq 5 \mathrm{mg} / \text { day for } \geq 3 \text { months }\end{array}$ & \\
\hline \multirow[t]{2}{*}{ SEIOMM (2015) [40] } & NA & $\begin{array}{l}\text { Postmenopausal women and men aged } \geq 50 \text { years } \\
\text { GC dose } \geq 5 \mathrm{mg} / \text { day for } \geq 3 \text { months }\end{array}$ & \\
\hline & & $\begin{array}{l}\text { Premenopausal women and men aged }<50 \text { years } \\
\text { Prior fragility fracture OR very low BMD OR very high dose GCs }\end{array}$ & \\
\hline SFR/GRIO (2014) [39] & $\begin{array}{l}\text { BMD (GC use } \geq 3 \text { months }) \\
\text { VFA (GC } \geq 7.5 \mathrm{mg} / \text { day for } \\
\geq 3 \text { months })\end{array}$ & $\begin{array}{l}\text { Postmenopausal women and men aged } \geq 50 \text { years } \\
\text { Prior fragility fracture OR age } \geq 70 \text { years OR GC } \geq 7.5 \mathrm{mg} / \text { day for } \\
\quad \geq 3 \text { months OR } \\
\text { BMD T-score } \leq-2.5 \text { OR } \\
\text { FRAX (GC-adjusted) above intervention threshold (when not applicable } \\
\text { of above indications) } \\
\text { Premenopausal women and men aged }<50 \text { years } \\
\text { GC use } \geq 3 \text { months plus fragility fracture }\end{array}$ & \\
\hline JSBMR (2014) [42] & $\begin{array}{l}\text { Score based on prior fragility } \\
\text { fracture, age, GC dose, and } \\
\text { lumbar spine BMD } \\
\text { (\% YAM) }\end{array}$ & Calculated individual patient's score $\geq 3$ & \\
\hline IOF-ECTS (2012) [37] & $\begin{array}{l}\text { FRAX (GC-adjusted) }{ }^{b} \\
\text { BMD (if available) at } \\
\text { intermediate risk }\end{array}$ & $\begin{array}{l}\text { Postmenopausal women and men aged } \geq 50 \text { years } \\
\text { Prior fragility fracture OR age } \geq 70 \text { years OR GC } \geq 7.5 \mathrm{mg} / \text { day for } \\
\geq 3 \text { months OR } \\
\text { BMD T-score } \leq-1.5 \text { OR FRAX above intervention threshold } \\
\text { Premenopausal women and men aged }<50 \text { years } \\
\text { GC use } \geq 3 \text { months plus fragility fracture }\end{array}$ & \\
\hline
\end{tabular}




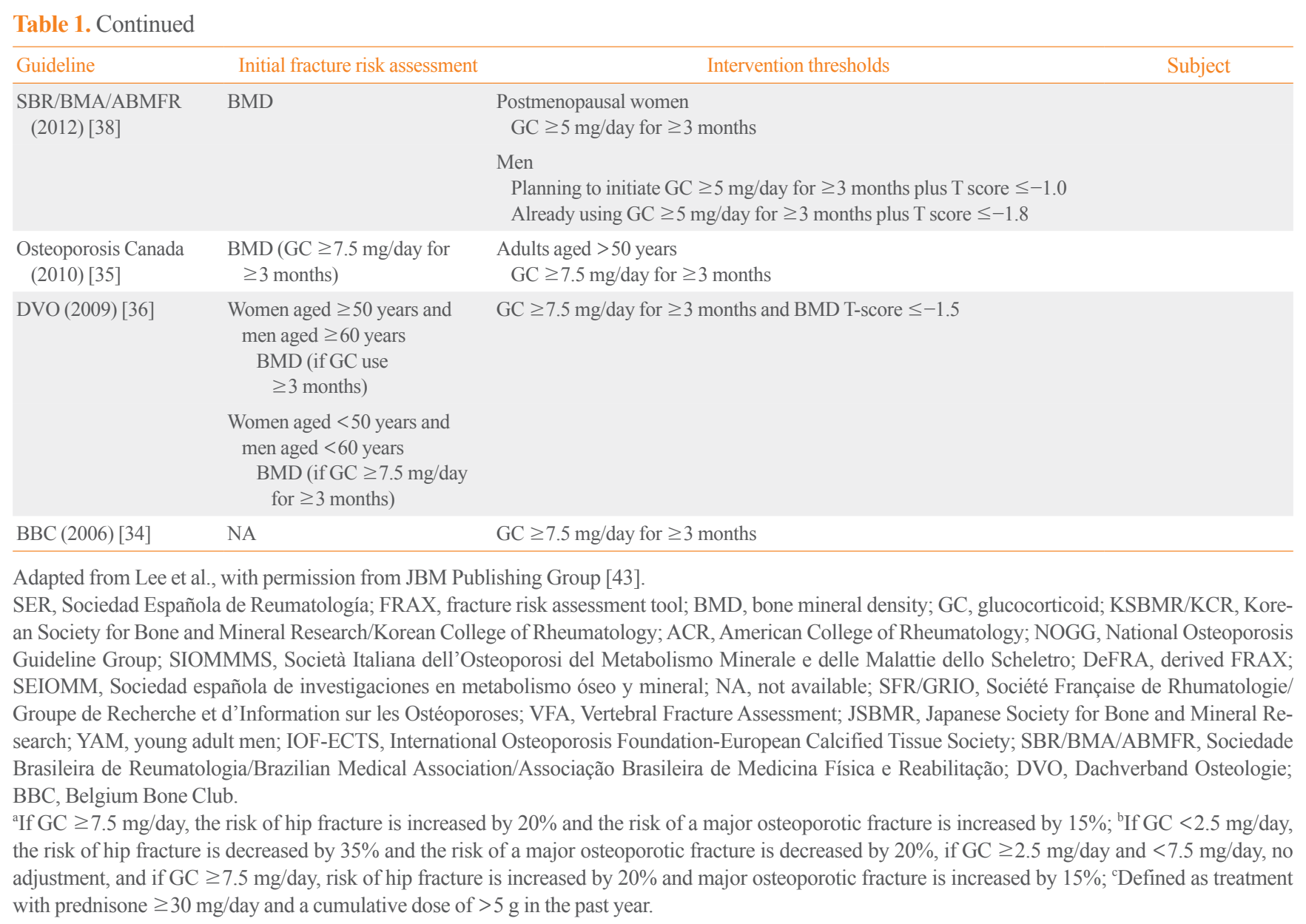

years of age whose 10-year probability of fracture estimated by the FRAX exceeds the intervention threshold at a given age. However, a fixed-probability intervention threshold was used for the ACR, KSBMR/KCR, and SER. The ACR and KSBMR/ KCR guidelines recommend a $10 \%$ probability of a major osteoporotic fracture and a $1 \%$ probability of a hip fracture.

\section{TREATMENT}

Oral bisphosphonates, such as alendronate and risedronate, have been shown to be effective as first line therapies in preventing fractures in GIOP, in addition to adequate calcium and vitamin D supplementation [12]. However, long-term use of bisphosphonates is associated with an increased risk of adverse events such as jaw necrosis or atypical femur fractures [44].

For postmenopausal women, selective estrogen receptor modulators prevent bone loss and lower the risk of fracture by decreasing osteoblast and osteoclast bone turnover [45]. One controlled trial demonstrated that raloxifene is an option for the prevention of BMD loss in postmenopausal women receiving long-term GC treatment [46]. Recently, we performed an RCT to evaluate the effectiveness of bazedoxifene in postmenopausal women with RA receiving GCs. Although bazedoxifene improved BMD and reduced bone turnover markers, it failed to prove a significant BMD change exceeding the least significant change [47].

In recent years, more potent intravenous antiresorptive agents, zoledronic acid [48], and denosumab have been shown to be superior to risedronate in facilitating a BMD increase in patients with GIOP [49]. However, evidence for the effectiveness of denosumab is limited to increasing BMD; therefore, further observational studies are needed to evaluate the effectiveness of denosumab in preventing fractures. Previous studies have shown that denosumab has the potential to prevent joint destruction in patients with early RA [50,51]. Given that RA patients frequently use GCs at an early stage, which results in an increased risk of fracture due to GIOP, denosumab may be a potentially useful treatment option for early RA patients to protect both joint de- 
struction and fracture occurrence. However, when using denosumab, it is important to recognize the rapid offset of the antiresorptive effect if the 6-monthly injection is delayed [52]. Shortterm or intermittent use of denosumab probably has no net benefit, as discontinuation of treatment is followed by rapid bone loss and an increased risk of multiple vertebral fractures [52]. Both patients and doctors need to understand this phenomenon before therapy is initiated and have a strategy for transitioning to another therapy, such as a bisphosphonate, if denosumab is discontinued [53].

However, antiresorptive agents may not be sufficient for osteoporosis caused by long-term GC use, particularly within the low-turnover state of the disease [54]. The effect of GCs on bones is also mediated by a decrease in bone formation due to a decrease in osteoblast production and activity [55].

Anabolic therapies protect against bone degradation by promoting new bone growth, rather than by reducing remodeling [55]. Teriparatide, a subcutaneous recombinant human parathyroid hormone, is the first anabolic agent approved for the treatment of osteoporosis. Teriparatide was approved by the U.S. Food and Drug Administration for postmenopausal women and men with osteoporosis in 2002. Subsequently, its preventive effect on vertebral fractures in GIOP was presented, but not in nonvertebral fractures [56,57]. Abaloparatide, a daily subcutaneous parathyroid hormone-related protein analog, has demonstrated significantly increased BMD at the lumbar spine and hip and reduced fracture incidence compared to placebo in postmenopausal women [55]. However, their use in GIOP has not yet been established. Romosozumab is a monoclonal antibody against sclerostin, a protein secreted by osteocytes that inhibits bone formation through the regulation of osteoblasts [58]. Although it has shown benefits in postmenopausal women and men [54], it has not yet been studied in patients on chronic GC treatment.

\section{CONCLUSIONS}

Since the introduction of the FRAX, a FRAX-based assessment of fracture risk has been used. However, high-quality data on treatment thresholds to prevent GIOP are limited. Along with efforts to identify potential biomarkers to predict the risk of individual osteoporotic fractures [59], further delicate criteria for individual patients are needed. In addition, many osteoporotic fractures occur in patients with osteopenia, because even though the risk of fracture is lower in osteopenia than in osteoporosis, the number of subjects at risk is much higher in the osteopenic range [60]. Therefore, early intervention in patients receiving long-term GC therapy is crucial to prevent the progression of osteopenia to osteoporosis.

\section{CONFLICTS OF INTEREST}

Yoon-Kyoung Sung has received research grants from BristolMyers Squibb, Eisai, Pfizer, and JW Pharmaceutical. SooKyung Cho has no conflict of interest.

\section{ORCID}

Soo-Kyung Cho https://orcid.org/0000-0003-4493-8837

Yoon-Kyoung Sung https://orcid.org/0000-0001-6691-8939

\section{REFERENCES}

1. Hench P. Effects of cortisone in the rheumatic diseases. Lancet 1950;2:483-4.

2. Lane NE, Lukert B. The science and therapy of glucocorticoid-induced bone loss. Endocrinol Metab Clin North Am 1998;27:465-83.

3. Overman RA, Yeh JY, Deal CL. Prevalence of oral glucocorticoid usage in the United States: a general population perspective. Arthritis Care Res (Hoboken) 2013;65:294-8.

4. Fardet L, Petersen I, Nazareth I. Prevalence of long-term oral glucocorticoid prescriptions in the UK over the past 20 years. Rheumatology (Oxford) 2011;50:1982-90.

5. Gudbjornsson B, Juliusson UI, Gudjonsson FV. Prevalence of long term steroid treatment and the frequency of decision making to prevent steroid induced osteoporosis in daily clinical practice. Ann Rheum Dis 2002;61:32-6.

6. Laugesen K, Jorgensen JOL, Sorensen HT, Petersen I. Systemic glucocorticoid use in Denmark: a population-based prevalence study. BMJ Open 2017;7:e015237.

7. Benard-Laribiere A, Pariente A, Pambrun E, Begaud B, Fardet L, Noize P. Prevalence and prescription patterns of oral glucocorticoids in adults: a retrospective cross-sectional and cohort analysis in France. BMJ Open 2017;7:e015905.

8. Oh TK, Song IA. Trends in long-term glucocorticoid use and risk of 5-year mortality: a historical cohort study in South Korea. Endocrine 2020;69:634-41.

9. Curtis JR, Westfall AO, Allison J, Bijlsma JW, Freeman A, George V, et al. Population-based assessment of adverse events associated with long-term glucocorticoid use. Arthritis Rheum 2006;55:420-6. 
10. Angeli A, Guglielmi G, Dovio A, Capelli G, de Feo D, Giannini $S$, et al. High prevalence of asymptomatic vertebral fractures in post-menopausal women receiving chronic glucocorticoid therapy: a cross-sectional outpatient study. Bone 2006;39:253-9.

11. Coulson KA, Reed G, Gilliam BE, Kremer JM, Pepmueller $\mathrm{PH}$. Factors influencing fracture risk, T score, and management of osteoporosis in patients with rheumatoid arthritis in the Consortium of Rheumatology Researchers of North America (CORRONA) registry. J Clin Rheumatol 2009;15: 155-60.

12. Chiodini I, Falchetti A, Merlotti D, Eller Vainicher C, Gennari L. Updates in epidemiology, pathophysiology and management strategies of glucocorticoid-induced osteoporosis. Expert Rev Endocrinol Metab 2020;15:283-98.

13. Van Staa TP, Leufkens HG, Abenhaim L, Zhang B, Cooper C. Use of oral corticosteroids and risk of fractures. J Bone Miner Res 2000;15:993-1000.

14. Briot K, Roux C. Glucocorticoid-induced osteoporosis. RMD Open 2015;1:e000014.

15. Hu K, Adachi JD. Glucocorticoid induced osteoporosis. Expert Rev Endocrinol Metab 2019;14:259-66.

16. Trijau S, de Lamotte G, Pradel V, Natali F, Allaria-Lapierre $\mathrm{V}$, Coudert H, et al. Osteoporosis prevention among chronic glucocorticoid users: results from a public health insurance database. RMD Open 2016;2:e000249.

17. Hardy RS, Zhou H, Seibel MJ, Cooper MS. Glucocorticoids and bone: consequences of endogenous and exogenous excess and replacement therapy. Endocr Rev 2018;39:519-48.

18. Compston J. Glucocorticoid-induced osteoporosis: an update. Endocrine 2018;61:7-16.

19. Swanson C, Lorentzon M, Conaway HH, Lerner UH. Glucocorticoid regulation of osteoclast differentiation and expression of receptor activator of nuclear factor-kappaB (NFkappaB) ligand, osteoprotegerin, and receptor activator of NF-kappaB in mouse calvarial bones. Endocrinology 2006; 147:3613-22.

20. Hofbauer LC, Gori F, Riggs BL, Lacey DL, Dunstan CR, Spelsberg TC, et al. Stimulation of osteoprotegerin ligand and inhibition of osteoprotegerin production by glucocorticoids in human osteoblastic lineage cells: potential paracrine mechanisms of glucocorticoid-induced osteoporosis. Endocrinology 1999;140:4382-9.

21. Jia D, O'Brien CA, Stewart SA, Manolagas SC, Weinstein RS. Glucocorticoids act directly on osteoclasts to increase their life span and reduce bone density. Endocrinology
2006;147:5592-9.

22. Ito S, Suzuki N, Kato S, Takahashi T, Takagi M. Glucocorticoids induce the differentiation of a mesenchymal progenitor cell line, ROB-C26 into adipocytes and osteoblasts, but fail to induce terminal osteoblast differentiation. Bone 2007; 40:84-92.

23. Colditz J, Thiele S, Baschant U, Garbe AI, Niehrs C, Hofbauer LC, et al. Osteogenic Dkk1 mediates glucocorticoidinduced but not arthritis-induced bone loss. J Bone Miner Res 2019;34:1314-23.

24. Ohnaka K, Tanabe M, Kawate H, Nawata H, Takayanagi R. Glucocorticoid suppresses the canonical Wnt signal in cultured human osteoblasts. Biochem Biophys Res Commun 2005;329:177-81.

25. Seibel MJ, Cooper MS, Zhou H. Glucocorticoid-induced osteoporosis: mechanisms, management, and future perspectives. Lancet Diabetes Endocrinol 2013;1:59-70.

26. van Staa TP, Leufkens HG, Abenhaim L, Zhang B, Cooper C. Oral corticosteroids and fracture risk: relationship to daily and cumulative doses. Rheumatology (Oxford) 2000;39: 1383-9.

27. Kim D, Cho SK, Park B, Jang EJ, Bae SC, Sung YK. Glucocorticoids are associated with an increased risk for vertebral fracture in patients with rheumatoid arthritis. J Rheumatol 2018;45:612-20.

28. van Staa TP, Leufkens HG, Cooper C. The epidemiology of corticosteroid-induced osteoporosis: a meta-analysis. Osteoporos Int 2002; 13:777-87.

29. De Vries F, Bracke M, Leufkens HG, Lammers JW, Cooper C, Van Staa TP. Fracture risk with intermittent high-dose oral glucocorticoid therapy. Arthritis Rheum 2007;56:20814.

30. Park SY, Gong HS, Kim KM, Kim D, Kim HY, Jeon CH, et al. Korean guideline for the prevention and treatment of glucocorticoid-induced osteoporosis. J Bone Metab 2018;25: 195-211.

31. Compston J, Cooper A, Cooper C, Gittoes N, Gregson C, Harvey N, et al. UK clinical guideline for the prevention and treatment of osteoporosis. Arch Osteoporos 2017;12:43.

32. Naranjo Hernandez A, Diaz Del Campo Fontecha P, Aguado Acin MP, Arboleya Rodriguez L, Casado Burgos E, Castaneda S, et al. Recommendations by the Spanish Society of Rheumatology on Osteoporosis. Reumatol Clin 2019;15: 188-210.

33. Buckley L, Guyatt G, Fink HA, Cannon M, Grossman J, Hansen KE, et al. 2017 American College of Rheumatology 
guideline for the prevention and treatment of glucocorticoidinduced osteoporosis. Arthritis Rheumatol 2017;69:1521-37.

34. Devogelaer JP, Goemaere S, Boonen S, Body JJ, Kaufman JM, Reginster JY, et al. Evidence-based guidelines for the prevention and treatment of glucocorticoid-induced osteoporosis: a consensus document of the Belgian Bone Club. Osteoporos Int 2006;17:8-19.

35. Papaioannou A, Morin S, Cheung AM, Atkinson S, Brown JP, Feldman S, et al. 2010 Clinical practice guidelines for the diagnosis and management of osteoporosis in Canada: summary. CMAJ 2010;182:1864-73.

36. DVO Guideline 2009 for prevention, diagnosis and therapy of osteoporosis in adults. Osteologie 2011;20:55-74.

37. Lekamwasam S, Adachi JD, Agnusdei D, Bilezikian J, Boonen S, Borgstrom F, et al. A framework for the development of guidelines for the management of glucocorticoidinduced osteoporosis. Osteoporos Int 2012;23:2257-76.

38. Pereira RM, Carvalho JF, Paula AP, Zerbini C, Domiciano $\mathrm{DS}$, Gonçalves $\mathrm{H}$, et al. Guidelines for the prevention and treatment of glucocorticoid-induced osteoporosis. Rev Bras Reumatol 2012;52:580-93.

39. Briot K, Cortet B, Roux C, Fardet L, Abitbol V, Bacchetta J, et al. 2014 Update of recommendations on the prevention and treatment of glucocorticoid-induced osteoporosis. Joint Bone Spine 2014;81:493-501.

40. Gonzalez-Macias J, Del Pino-Montes J, Olmos JM, Nogues $\mathrm{X}$; en nombre de la Comision de Redaccion de las Guias de Osteoporosis de la SEIOMM. Clinical practice guidelines for posmenopausal, glucocorticoid-induced and male osteoporosis. Spanish Society for Research on Bone and Mineral Metabolism (3rd updated version 2014). Rev Clin Esp 2015; 215:515-26.

41. Rossini M, Adami S, Bertoldo F, Diacinti D, Gatti D, Giannini S, et al. Guidelines for the diagnosis, prevention and management of osteoporosis. Reumatismo 2016;68:1-39.

42. Suzuki Y, Nawata H, Soen S, Fujiwara S, Nakayama H, Tanaka I, et al. Guidelines on the management and treatment of glucocorticoid-induced osteoporosis of the Japanese Society for Bone and Mineral Research: 2014 update. J Bone Miner Metab 2014;32:337-50.

43. Lee TH, Song YJ, Kim H, Sung YK, Cho SK. Intervention thresholds for treatment in patients with glucocorticoid-induced osteoporosis: systematic review of guidelines. J Bone Metab 2020;27:247-59.

44. Suresh E, Pazianas M, Abrahamsen B. Safety issues with bisphosphonate therapy for osteoporosis. Rheumatology
(Oxford) 2014;53:19-31.

45. Ettinger B, Black DM, Mitlak BH, Knickerbocker RK, Nickelsen T, Genant HK, et al. Reduction of vertebral fracture risk in postmenopausal women with osteoporosis treated with raloxifene: results from a 3-year randomized clinical trial. Multiple Outcomes of Raloxifene Evaluation (MORE) Investigators. JAMA 1999;282:637-45.

46. Mok CC, Ying KY, To CH, Ho LY, Yu KL, Lee HK, et al. Raloxifene for prevention of glucocorticoid-induced bone loss: a 12-month randomised double-blinded placebo-controlled trial. Ann Rheum Dis 2011;70:778-84.

47. Cho SK, Kim H, Lee J, Lee S, Choi YY, Sung YK. Effectiveness of bazedoxifene in the prevention of glucocorticoid-induced bone loss in RA patients. Proceedings of the 13th International Symposium, Korean College of Rheumatology; 2019 May 16-18; Seoul, KR. Seoul: Korean College of Rheumatology; 2019. p. 328.

48. Reid DM, Devogelaer JP, Saag K, Roux C, Lau CS, Reginster JY, et al. Zoledronic acid and risedronate in the prevention and treatment of glucocorticoid-induced osteoporosis (HORIZON): a multicentre, double-blind, double-dummy, randomised controlled trial. Lancet 2009;373:1253-63.

49. Saag KG, Wagman RB, Geusens P, Adachi JD, Messina OD, Emkey R, et al. Denosumab versus risedronate in glucocorticoid-induced osteoporosis: a multicentre, randomised, double-blind, active-controlled, double-dummy, non-inferiority study. Lancet Diabetes Endocrinol 2018;6: 445-54.

50. Takeuchi T, Tanaka Y, Soen S, Yamanaka H, Yoneda T, Tanaka S, et al. Effects of the anti-RANKL antibody denosumab on joint structural damage in patients with rheumatoid arthritis treated with conventional synthetic diseasemodifying antirheumatic drugs (DESIRABLE study): a randomised, double-blind, placebo-controlled phase 3 trial. Ann Rheum Dis 2019;78:899-907.

51. Ishiguro N, Tanaka Y, Yamanaka H, Yoneda T, Ohira T, Okubo N, et al. Efficacy of denosumab with regard to bone destruction in prognostic subgroups of Japanese rheumatoid arthritis patients from the phase II DRIVE study. Rheumatology (Oxford) 2019;58:997-1005.

52. Popp AW, Zysset PK, Lippuner K. Rebound-associated vertebral fractures after discontinuation of denosumab-from clinic and biomechanics. Osteoporos Int 2016;27:1917-21.

53. Horne AM, Mihov B, Reid IR. Bone loss after romosozumab/denosumab: effects of bisphosphonates. Calcif Tissue Int 2018;103:55-61.

54. Chiodini I, Merlotti D, Falchetti A, Gennari L. Treatment 
options for glucocorticoid-induced osteoporosis. Expert Opin Pharmacother 2020;21:721-32.

55. Taylor AD, Saag KG. Anabolics in the management of glucocorticoid-induced osteoporosis: an evidence-based review of long-term safety, efficacy and place in therapy. Core Evid 2019;14:41-50.

56. Saag KG, Shane E, Boonen S, Marin F, Donley DW, Taylor $\mathrm{KA}$, et al. Teriparatide or alendronate in glucocorticoid-induced osteoporosis. N Engl J Med 2007;357:2028-39.

57. Saag KG, Zanchetta JR, Devogelaer JP, Adler RA, Eastell R, See K, et al. Effects of teriparatide versus alendronate for treating glucocorticoid-induced osteoporosis: thirty-six- month results of a randomized, double-blind, controlled trial. Arthritis Rheum 2009;60:3346-55.

58. Cosman F, Crittenden DB, Adachi JD, Binkley N, Czerwinski E, Ferrari S, et al. Romosozumab treatment in postmenopausal women with osteoporosis. N Engl J Med 2016;375: 1532-43.

59. Kim BJ, Lee SH, Koh JM. Potential biomarkers to improve the prediction of osteoporotic fractures. Endocrinol Metab (Seoul) 2020;35:55-63.

60. Eriksen EF. Treatment of osteopenia. Rev Endocr Metab Disord 2012;13:209-23. 